\title{
TELAAH HERMENEUTIKA DALAM KITAB TA'WIL MUKHTALIF AL-HADITS KARANGAN IBN QUTAYBAH
}

\author{
Muhammad Sakti Garwan \\ Institut Agama Islam Negeri Ternate \\ Email: m.saktigarwan10@gmail.com
}

\begin{abstract}
This article examines the book Ta'wil Mukhtalif al-Hadits, written by Ibn Qutaybah. This book is compiled in response to the political turmoil that occurred during his lifetime. Ibn Qutaybah also wanted to dispel the assumption that some groups who accused the scholars of hadith, had committed negligence, by narrating hadiths that are in conflict with each other that are not in line with the Qur'an and the understanding of reason. This study uses the library method by making the book Ta'mil Mukbtalif al-Hadits the primary source. In addition, the author uses the theory of hermeneutics as an analytical tool to categorize this book as a hermeneutic book of classical hadith. The results of the study stated that the book Ta'wil Mukhtalif al-Hadits has its own characteristics in looking at the hadith that seem to be contradictory but in terms of meaning is not, and also he took excellent steps in completing a hadith of the Prophet Muhammad saw., in that method and step until the book Ta'wil Mukbtalif al-Hadits is categorized as a hermeneutic book of classical hadith.
\end{abstract}

Keywords: Hermeneutics, Ibn Qutaybah, Ta'wil Mukhtalif al-Hadits

\begin{abstract}
Abstrak
Tulisan ini menelaah kitab Ta'wil Mukhtalif al-Hadits, yang dikarang oleh Ibn Qutaybah. Kitab ini disusun sebagai respons tentang pergolakan politik yang terjadi pada masa beliau hidup. Ibn Qutaybah juga ingin menepis anggapan sebagian golongan yang menuduh ulama hadis telah melakukan kecerobohan dengan meriwayatkan hadis yang saling berlawanan yang tidak sejalan dengan al-Qur'an dan pemahaman akal. Penelitian ini menggunakan metode kepustakaan dengan menjadikan kitab Ta'wil Mukhtalif al-Hadits sebagai sumber primer. Selain itu, penulis menggunakan teori hermeneutika sebagai alat analisis untuk mengategorikan kitab ini sebagai kitab hermeneutika hadis klasik. Hasil penelitian menyatakan bahwa kitab Ta'wil Mukhtalif al-Hadits mempunyai karakteristik tersendiri dalam melihat hadis-hadis yang kelihatan saling
\end{abstract}


kontra namun pada segi maknanya tidak, dan juga beliau mengambil langkah-langkah yang sangat baik dalam penyelesaian suatu hadis Nabi Muhammad saw., dalam metode dan langkah itulah hingga kitab Ta'wil Mukhtalif al-Hadits ini dikategorikan sebagai kitab hermeneutika hadis klasik.

Kata Kunci: Hermeneutika, Ibn Qutaybah, Ta'wil Mukhtalif al-Hadits

\section{Pendahuluan}

Nabi Muhammad saw. menurut al-Qur'an adalah Rasul utusan Allah, Nabi yang terakhir, pembawa ajaran agama Islam yang mana perilaku dari Nabi saw. merupakan teladan yang baik, dan kehadirannya membawa berita yang mengembirakan dan berita yang menakutkan, selain itu kehadirannya merupakan rahmat bagi semesta alam. ${ }^{1}$ Dalam menafsirkan apa yang ada di dalam al-Qur'an juga, baik itu global, metaforik, ataupun yang bebas (mutlak), Nabi Muhammad saw. adalah sumber yang paling berhak dalam peringkat pertama. Oleh karena itu, Allah Swt. menurunkan hadis kepada Rasulullah dalam rangka penerapan nilai-nilai al-Qur'an dalam kehidupan manusia.

Hal inilah yang membuat kita sebagai umatnya dituntut untuk mengikuti setiap apa yang dibuat dan dikatakan lewat hadishadis dari Nabi saw. kemudian memahaminya dengan baik dan benar. Pemahaman terhadap sebuah hadis haruslah dilakukan dengan baik untuk mendapatkan makna yang sesungguhnya sesuai apa yang menjadi maksud dari Nabi Muhammad saw. Dikarenakan hal ini sangatlah penting untuk melihat sebuah permasalahan yang terjadi pada era sekarang ini, jika disinggungkan dengan sebuah hadis Nabi. Inilah yang menjadi sebuah landasan hingga tercipta ilmu untuk memahami hadis Nabi saw. yang sangat baik yakni ilmu Mukhtalif al-Hadits, yang mana dengan memahami ilmu ini sesorang akan terhindar dari kekeliruan dan kesalahan dalam memahami hadis-hadis mukbtalif atau hadis yang kontradiktif.

1 M. Syuhudi Ismail, Hadis Nabi Menurut Pembela Pengingkar dan Pemalsunya, (Jakarta: Gema Insani Press, 1995), hlm. 109. 
Hasil dari ilmu Mukbtalif al-Hadits ini dalam memahami hadis-hadis nabi ini, kemudian para ulama yang tentunya telah mengerahkan upaya mereka dalam segala hal untuk menjaga kemuliaan hadis Nabi, menjaga dari segala apa yang dapat meruntuhkan hadis itu sendiri, melalui pemikiran-pemikiran yang juga disusun dalam sebuah kitab agar dapat memahami hadis-hadis Nabi Muhammad saw. yang mukhtalif atau bertentangan. Salah satu di antaranya adalah seorang ulama hadis yang sangat populer yakni Ibn Qutaybah dalam kitabnya Ta'wil Mukbtalif al-Hadits atau hadishadis yang dinilai kontradiktif, yang menjadi objek pembahasan dalam penulisan artikel ini.

Dalam penyusunan kitab tersebut terdapat kitab serupa yang ditulis oleh para ulama-ulama besar lainnnya menurut urutan penulisannya yakni Imam al-Syafi'i (w. 203 H) dengan karyanya yang berjudul Ikbtilaf al-Hadits, kemudian disusul oleh kitab dari Ibn Qutaybah (w. 276 H) dengan judul Ta'wil Mukbtalif al-Hadits, ada pula karya al-Tahawi (w. $321 \mathrm{H}$ ) yaitu Musykil al-Atsar, Abu Bakr Muhammad bin al-Hasan (Ibn Furaq) (w. 406 H) yaitu Musykil al-Hadits wa Bayanubu, dan lain-lain. ${ }^{2}$

Karya dari Ibn Qutaybah ini yakni Ta'wil Mukbtalif al-Hadits adalah hasil karya terpenting miliknya dan sekaligus merupakan respons terhadap cerminan zamannya pada saat itu yang mana terjadi pembelaan hadis dari serangan musuh Islam. Yang mana kemudian dalam kitabnya Ibn Qutaybah menggambarkan betapa gencarnya serangan terhadap hadis pada masa itu. Hal inilah yang membuat Ibn Qutaybah menyusun kitab tersebut untuk menyelesaikan hadis-hadis yang tampak saling bertentangan dan juga dikarenakan banyaknya kalangan yang menolak hadis-hadis yang dianggap saling bertentangan. ${ }^{3}$

2 Muhammad 'Ajjaj al-Khatib, Ushul al-Hadits Ulumubu wa Musthalabubu (Beirut: Dar al-Fikr, 2009), hlm. 184.

3 Azyumardi Azra dkk, Ensiklopedi Islam, vol III (Jakarta: Ikhtiar Baru van Hoeve, 2005), hlm. 96. 
Dalam menyusun kitabnya juga Ibn Qutaybah memiliki karakteristik tersendiri dan juga cara penyelesaiannya dalam memahami hadis-hadis yang tampaknya saling bertentangan. Karena, seperti yang telah disinggung bahwa ada sebagian kelompok yang menolak adanya pertentangan dalam hadis, bahkan ada yang berpendapat bahwa hadis itu bukan dari Nabi saw., yang mana hal ini akan penulis cantumkan dalam artikel ini.

Studi pemikiran Islam zaman modern ini, hermeneutika merupakan tren baru yang sebelumnya tidak mendapat cukup banyak perhatian dari sarjana dan cendikiawan muslim. Hermeneutika mulai banyak digemari setelah informasi dan pengetahuan tentangnya banyak menggeliat setelah banyak tulisan dan karya yang muncul dari penulis dan cendikiawan Arab kontemporer. Hal tersebutlah yang membuah penulis dalam artikel ini juga akan mencoba mengategorikan kitab ini sebagai sebuah kitab hermeneutika, yakni sebuah pendekatan yang dianggap baru dalam disiplin keilmuan modern, namun dari segi metodenya sudah dicontohkan oleh ulama dalam kitab-kitabnya dalam ranah kitab klasik.

\section{Pembahasan}

\section{Sekilas Tentang Hermeneutika Hadis}

Hermeneutika (hermeneutics), secara etimilogis berasal dari bahasa Yunani Hermeneuo atau bermeneuien. Pada masa tradisi Yunani kuno, kata hermenexien atau hermeneia adalah sebuah bentuk kata benda. Ada tiga makna yang dimikili oleh hermeneutika itu sendiri, yakni: mengatakan (to say); menjelaskan (to explain); dan menerjemahkan (to translate). Tiga makna inilah kemudian dipahami sebuah "to interpret" dalam bahasa Inggris. Hal tersebutlah yang membuat hermeneutika dapat dipahami sebagai sebuah interpretasi yang menunjukkan pada tiga hal pokok, yaitu pengucapan lisan, 
penjelasan yang masuk akal, dan terjemahan dari bahasa lain. ${ }^{4}$ Yang tentunya dapat dilihat dari berbagai metode dalam mengungkap sebuah makna, dalam hal ini makna dari hadis nabi saw.

Salah satu tokoh hermeneutika asal Indonesia, Sahiron Syamsuddin juga mengatakan, bahwa integrasi hermeneutika dalam arti luas, dapat mencakup Hermeneuse (praktik penafsiran), hermeneutics (hermeneutika dalam arti sempit, yakni ilmu tentang metode-metode penafsiran), philosopical hermeneutics (hermeneutika filosofis), dan hermeneutical philosophy (filsafat hermeneutis). ${ }^{5}$

Dalam kajian pada ranah al-Qur'an dan Hadis, tentu masih diperdebatkan terutama di kalangan pemikir Muslim. Dikarenakan banyak dari mereka yang menolak secara keseluruhan, sementara sebagian lain menerima hermeneutika ini secara keseluruhan serta bahkan ada sebagian lagi menerima dan atau menolaknya tidak secara keseluruhan karena adanya pertimbangan tertentu dari mereka. Dalam penjelasan di atas dapat dikatakan bahwa hermeneutika hadis adalah sebuah upaya memahami, menjelaskan, dan menafsirkan hadis Nabi Muhammad saw. terutama hadis-hadis yang masih banyak diperdebatkan.

\section{Mengenal Ibn Qutaybah}

Ibn Qutaybah mempunyai nama lengkap yakni 'Abdullah bin Muslim bin Qutaybah al-Daynuri al-Marwazi. Ayah dari Ibn Qutaybah bernama Abu Muhammad, beliau dinisbatkan pada alDaynuri dikarenakan beliau pernah menjadi hakim di sana di daerah tersebut. Sebagian ulama berpendapat bahwa Ibn Qutaybah juga dinisbatkan kepada al-Marwazi yang merupakan tempat kelahiran dari ayahnya. ${ }^{6}$

${ }^{4}$ Nasaruddin Umar, Deradikalisasi Pemahaman Alquran dan Hadis (Jakarta: PT Elex Media Komputindo, 2014), hal. 66.

5 Kurdi dkk, Hermeneutika al-Qur'an dan Hadis, disunting oleh Sahiron Syamsuddin (Yogyakarta: eLSAQ Press, 2010), hlm. v.

${ }^{6}$ Abu Muhammad 'Abdullah bin Muslim bin Qutaybah, Ta'wil Mukbtalif alHadits (Beirut: al-Maktab al-Islami, 1999), hlm. 22. 
Ibn Qutaybah lahir pada tahun 213 H./828 M. di Baghdad, ada sebagian yang mengatakan bahwa ia dilahirkan di Kuffah. Pada saat itu, Baghdad merupakan ibu kota negara yang berada di dekat bekas ibu kota Persia. Dapat dikatakan bahwa pusat pemerintahan dinasti Abbasiyah berada di tengah-tengah bangsa Persia. Sejak saat itu, Baghdad tidak pernah sepi dari perkembangan ilmu pengetahuan dan kemunculan ulama-ulama besar.

Sejak remaja Ibn Qutaybah sangat aktif belajar ilmu bahasa dan ilmu-ilmu syariat. Ia belajar hadis pada ulama-ulama hadis terkenal pada saat itu semisal Ishaq bin Rahawaih, Muhammad bin Ziyad bin Ubaidillah al-Ziyadi. Begitu pula halnya Ibn Qutaibah belajar bahasa, nahwu dan qiraat pada Abu Hatim Sajastani. Dan masih banyak lagi para ulama yang beliau datangi untuk mempelajari ilmu agama dan bahasa, seperti Harmalah bin Yahya, Abul Khathab Ziyad bin Yahya al-Hassani. Ibn Qutaibah pernah menjabat Qadi di wilayah Dinawar. Beliau meninggal pada bulan Rajab tahun $276 \mathrm{H}$. bertepatan tahun $889 \mathrm{M}^{7}$

Dalam bidang fikih, Ibn Qutaybah senantiasa berada di barisan madzhab-madzhab ulama yang teguh memegang sunnah yang berkembang pada waktu itu, meskipun secara pribadi dia mengikuti maḑ̌hab Imam Ahmad dan Imam Ishaq. ${ }^{8}$ Ibn Qutaybah juga merupakan juru bicara Abl al-Sunnah wa al-Jama'ah, dikarenakan ia merupakan seorang ulama yang berpegang kepada sunnah dan membelanya ketika mendapat serangan gencar. Pada masa hidupnya, di pusat negara Islam Abbasiyah, Baghdad, berkembang banyak aliran pemikiran selain pemikiran Islam, antara lain, budaya Yunani yang masuk melalui kegiatan penerjemahan, budaya Persia yang membawa masuk pemikiran atheis, budaya asli Arab yang sudah bercampur dengan banyak budaya asing. Ibn Qutaybah dalam hal ini memilih jalannya sendiri, yaitu berada dalam

7 Badri Yatim, Sejarah Peradaban Islam (Jakarta: Raja Grafindo Persada, 1995), hlm. 51.

${ }^{8}$ Muhammad Abu Zahw, al-Hadits wa al-Muhadditsun (Riyadh: al-Maktabah al- 'Arabiyyah al-Su'udiyyah, 1984), hlm. 362. 
golongan Abl al-Sunnah, yang terpengaruh oleh pendekatan ahli hadis. ${ }^{9}$ Hal tersebut tergambar pada kitab Ta'wil Mukbtalif al-Hadits yang dikarang oleh beliau dan juga merupakan karya terpenting milik beliau. Ibn Qutaybah mempunyai guru-guru dalam meriwayatkan hadis-hadis, beberapa di antaranya adalah Muslim bin Qutaybah (Ayah dari Ibn Qutaybah), Ahmad bin Sa'id alHayyani, Abu 'Abd Allah Muhammad bin Salam al-Jamhi (w. 321 H) dan beberapa guru lainnya. Sedangkan ulama yang berguru pada beliau atau murid-murid yang meriwayatkan hadis dari Ibn Qutaybah beberapa di antaranya adalah Ahmad bin Abdullah bin Muslim (w. 322 H), Ahmad bin Marwan al-Maliki (w. 298 H), Muhammad bin Khalaf bin al-Murzaban (w. 309 H), dan beberapa murid lainnya. ${ }^{10}$

Ibn Qutaybah adalah seorang ulama yang sangat produktif dalam menulis kitab-kitab ilmu Islam, banyak karya-karya beliau yang sangat luar biasa selain dari kitab Ta'wil Mukhtalif al-Hadits yang sangat luar biasa ini, beberapa kitab yang ditulisnya adalah Musykil al-Qur'an, Ma'an li al-Qur'an, Al-Qira'at, I'rab al-Qira'at, AlRadd 'ala al-Qail bi Khalq al-Qur'an, Adab al-Qira'at, Gharib al-Hadits, Islah Ghalat Abu Ubaydah, Al-Masail wa al-Ajwibah, Kitab al-Ilm, dan lainnya. ${ }^{11}$

\section{Deskripsi dan Sejarah Penulisan Kitab Ta'wil Mukhtalif al- Hadits}

Kata ta'wil berasal dari kata ala-yaulu-aulan yang berarti "kembali kepada asal". Ada yang berpendapat bahwa ta'wil berasal dari kata iyalah yang berarti mengatur, seorang mu'awwil (penakwil) seakan-akan sedang mengatur perkataan dan meletakkan makna sesuai dengan tempatnya. ${ }^{12}$ Menakwil kalam berarti menjelaskan

${ }^{9}$ Azyumardi Azra, dkk, Ensiklopedi Islam Vol. III., hlm. 96.

10 Ibn Qutaybah, Ta'mil Mukbtalif al-Hadis, hlm. 6-7.

11 Azyumardi Azra, dkk, Ensiklopedi Islam, vol III, hlm. 95.

${ }^{12}$ Louis Ma'luf, Al-Munjid fi al-Lughah, (Beirut Darul-Masyriq, 2002), Cet. Ke-39, hlm. 21. 
dan mengembalikan kepada maksud yang diharapkan. Ibnu Manzur mendefinisikan ta'wil secara etimologis yang berarti ruju' (kembali) seperti bunyi hadis "man shama al-dahr fala shama wala ala" (barang siapa yang puasa selamanya maka sebenarnya dia tidak puasa dan tidak kembali kepada kebaikan). ${ }^{13}$

Dalam analisa penulis ta'mil dapat berarti menjelaskan makna yang kurang jelas pada suatu hadis. Dengan kata lain, kesan dari ta'wil itu untuk mencari ta'aruf atau pengenalan dengan al-Qur'an, dikarenakan jika ta'aruf dengan hadis yang tampak tidak masuk akal maka dilakukan ta'wil. Ta'aruf di sini dapat berarti dalam segi derajat. Dalam analisa penulis juga pada ranah dalam hal hukum meninggalkan ta'wil adalah bersifat relatif dikarenakan lihat konteknya terlebih dahulu, tetapi hal ini sangat dibutuhkan karena dalam hal ini berguna bagi kita semua dalam memaknai sebuah hadis.

Ibn Qutaybah menggunakan nama ta'wil karena adanya konflik teologis yang terjadi pada saat itu, dimana kata ta'wil digunakan karena metode tersebut juga cukup familier dan dibutuhkan pada saat itu, karena orang-orang yang hidup pada masa itu membutuhkan penjelas terhadap hadis-hadis Nabi saw. yang dinilai kontradiktif. Dan juga tujuan dari penamaan Ta'wil Mukhtalif al-Hadits adalah sebagai li daf' al-sunnah, artinya pembelaan sunnab atau hadis Nabi saw. ${ }^{14}$

Dari segi penamaan kitab yakni Mukhtalif al-Hadits secara bahasa dapat dipahami dengan hadis-hadis yang bertentangan. Sedangkan dalam bidang 'Ulum al-Hadits istilah ini diperuntukkan nama dari adanya dua hadis yang sama-sama sahih yang secara lahir terlihat bertentangan, namun pada substansinya tidak. ${ }^{15}$ Dari sini, dapat dilihat bahwasanya isi kitab yang ditulis oleh Ibn Qutaybah,

${ }^{13}$ Ibnu Manzhur, Lisanul Arab, (Beirut Darul Fikr, 1990), Jilid I, hlm. 33.

14 Penjelasan Prof. Dr. Abdul Mustaqim, dalam kuliah hermeneutika hadis, di kelas Studi Qur'an Hadis.

15 Ahmad Umar Hasyim, Qawa'id Ushul al-Hadits (Beirut: Alimul Kutub, 1997), hlm. 203. 
merupakan pembahasan mengenai hadis-hadis yang bertentangan namun secara substansinya tidak. Yang mana beliau mendudukkan hadis-hadis tersebut dengan posisi yang baik.

Ibn Qutaybah hidup pada masa Daulah Bani Abbasiyah, yang pusat kekuasaannya terletak di kota Bahgdad. Ia hidup pada masa Khalifah al-Mutawakkil sejak tahun 232 H/847 M. Pada masa ini, keadaan politik dan militer mulai mengalami kemerosotan, namun bertolak belakang dalam bidang ilmu pengetahuan, sebab ilmu pengetahuan semakin mengalami kemajuan, tidak terkecuali dalam bidang ilmu hadis. Kemajuan pengetahuan ini disebabkan negara-negara bagian dari kerajaan Islam tetap berlomba-lomba dalam memberi penghargaan atau kedudukan terhormat kepada para ulama dan para pujangga.

Seiring dengan bertambah maju ilmu pengetahuan, banyak pula bermunculan gerakan-gerakan politik yang mengatasnamakan agama, sebagai kelanjutan dari masa sebelumnya. Gerakan politik ini muncul baik dalam rangka mendukung pemerintah maupun melakukan oposisi, seperti revolusi Khawarij di Afrika Utara, gerakan Zindiq di Persia, gerakan Syi'ah, Murji'ah, Ahl al-Sunnah dan Mu'tazilah.

Ketegangan semakin memuncak ketika kaum Mu'tazilah mendapat angin segar dari penguasa pada waktu itu ketika pemerintahan (kekhalifahan) dipegang oleh al-Ma'mun (w. 218 $\mathrm{H} / 833 \mathrm{M})$ yang dengan tegas mendukung pendapat-pendapat Mu'tazilah. ${ }^{16}$ Keadaan yang sangat tidak menguntungkan bagi ulama hadis ini tetap berlanjut pada masa kehalifahan al-Mu'tasim (w. 227 H/842 M) dan al-Watsiq (w. 232 H/846 M). Ulama hadis mulai mendapat kelonggaran ketika tongkat kekhalifahan dipegang oleh al-Mutawakkil, yang memiliki kepedulian terhadap ilmu-ilmu hadis. ${ }^{17}$

${ }^{16}$ Ibn Qutaybah, Ta'wil Mukhtalif al-Hadits, hlm. 10-24.

17 Ahmad Hasan, The Doctrine of Ijma' (Islamabad: Islamic Research Institute, 1978), hlm. 83. 
Sebagai seorang ulama yang santun, berilmu tinggi, dan berwawasan luas, Ibn Qutaybah merasa terpanggil untuk menancapkan kembali pondasi kebenaran dan kewibawaan Islam yang telah dicerai-beraikan oleh orang-orang yang tidak bertanggung jawab, melalui salah satu karyanya yang monumental yaitu kitab Ta'wil Mukhtalif al-Hadits. Di dalam karyanya tersebut, ia berusaha menepis anggapan sebagian golongan yang menuduh ulama hadis telah melakukan kecerobohan dengan meriwayatkan hadis yang dianggap saling berlawanan maupun tidak sejalan dengan al-Qur'an dan pemahaman akal, serta mengamalkan hadishadis yang bertentangan dengan kemahasucian Allah Swt. Maka dengan alasan itu, ia berupaya memberikan jawaban sebagai solusi pemecahan hadis-hadis tersebut berdasarkan pemikiran ijtihadnya. ${ }^{18}$

Hemat penulis dalam hal menakwilkan hadis tentunya kita membutuhkan kemampuan tertentu, dan hal itu sudah dimiliki oleh Ibn Qutaybah, dikarenakan beliau mempunyai atau menguasai banyak bidang ilmu, dan ketika ada hadis yang tidak bisa di-ta'milkan maka Ibn Qutaybah melakukan nasikh wa al-mansukh, kemudian tarjï. Apabila kemudian belum bisa lagi maka hal yang beliau lakukan adalah mengembalikan kepada Allah tentang pengetahuannya dan berdoa agar diberikan petunjuk dari Allah Swt. agar terlindung dari segala perbuatan atau penakwilan yang salah, karena beliau mengaku bahwa beliau masih mempunyai kekurangan.

\section{Karakteristik Kitab Ta'wil Mukhtalif al-Hadits}

Kitab Ta'wil Mukhtalif al-Hadits juga mempunyai karakteristik pada segi penyusunannya yakni sebagai berikut:

a. Dalam kitab Ta'wil Mukhtalif al-Hadits, terdapat 109 pembahasan yang terbagi menjadi beberapa bagian. Pertama adalah hadishadis yang dianggap bertentangan dengan hadis terdapat 66

\footnotetext{
${ }^{18}$ Ibn Qutaybah, Ta'wil Mukhtalif al-Hadits, hlm. 63.
} 
pembahasan, kedua adalah hadis-hadis yang bertentangan dengan al-Quran terdapat 13 pembahasan, kemudian hadishadis yang bertentangan dengan ijma' maupun rasio terdapat 16, dan hadis-hadis tentang tasybib terdapat 14 pembahasan. ${ }^{19}$

b. Dalam menyusun kitab Ta'wil Mukhtalif al-Hadits, Ibn Qutaybah mengawalinya dengan mukadimah panjang yang bermanfaat dan menerangkan latar belakang penulisan kitabnya tersebut dan juga maksud tujuan penulisannya. Selain itu, dalam mukadimahnya Ibn Qutaybah menerangkan perselisihan yang dilontarkan abl kalam dan membantah tuduhan mereka.

c. Kemudian Ibn Qutaybah mengakhiri mukadimahnya dengan menyebutkan keutamaan para abl al-badits, kemuliaannya, kelebihannya dan upaya-upaya abl al-badits dalam menjaga sunnah Rasul dan membelanya.

d. Setelah menyebutkan keutamaan ulama hadis, Ibn Qutaybah menyebutkan pembahasan-pembahasan tentang hadis mukhtalif, dan mempermudahnya dengan memberinya judul dalam setiap permasalahannya.

e. Pembahasan hadis-hadis yang bertentangan dalam kitab Ta'wil Mukbtalif al-Hadits, dimulai dengan hadis-hadis yang bertentangan dengan ayat-ayat al-Qur'an ataupun dengan hadis yang lain, kemudian dikomentari oleh Ibn Qutaybah dan dibantah tentang adanya ikhtilaf di antara hadis-hadis yang nampaknya bertentangan. Yaitu dengan diawali dengan jawaban yang menyangkal adanya pertentangan haqiqi di antara dua hadis maupun lebih, kemudian menyebutkan bukti-buktinya dan meluruskannya dengan alasan-alasan yang membatalkan perkataan-perkataan yang menunjukkan pertentangan.

f. Dalam beberapa hal, hadis-hadis yang dibahas dalam kitab Ta'wil Mukhtalif al-Hadits dijelaskan kualitas hadis-hadisnya secara global. Dalam menjawab dan menepis anggapan yang

${ }^{19}$ Ibn Qutaybah, Ta'wil Mukhtalif al-Hadits, hlm. 25.

TAJDID vol. 19, No. 2, Juli - Desember 2020 | 149 
mempertentangkan hadis, Ibn Qutaybah lebih banyak menggunakan pendekatan pemaknaan terhadap hadis-hadis yang dinilai bertentangan. Dan seterusnya sampai pada penutup kitab ini.

Dalam kitab Ta'wil Mukhtalif al-Hadits ini, disusun dalam beberapa sub-sub bab yang merangkum hadis-hadis yang kontradiktif tersebut, di antaranya adalah:

a. Hadis tentang beda pendapat di kalangan ahli kalam tentang dasar agama (al-Ushul), yang terdapat 16 hadis yang kontradiktif.

b. Hadis yang berbicara tentang kontradiksi Ubaidillah bin Hasan, yang berisi empat hadis.

c. Hadis tentang bantahan terhadap Ashab al-Ra'yi (kelompok rasionalitas), terdapat 13 hadis.

d. Hadis tentang perihal ahli hadis, yang berisi delapan hadis.

e. Hadis tentang kontradiktif dan kontra dengan al-Qur'an serta hadis yang ditolak berdasarkan analisis dan akal, yang berisi 43 hadis.

f. Hadis tentang hukum yang telah dianggap ijma' ulama lalu dibatalkan oleh al-Qur'an tetapi dijadikan dalil oleh orangorang Khawarij, yang berisi 63 hadis. ${ }^{20}$

\section{Langkah Penyelesaian Suatu Hadis dan Contoh Pengaplikasi Hadis Menurut Ibn Qutaybah dalam Kitab Ta'wil Mukhtalif al-Hadits}

Dalam penyelesaian hadis-hadis mukhtalif, Ibn Qutaybah melakukan beberapa langkah sebagai berikut dengan beberapa contoh yang relevan dalam penyelesaiannya menurut beliau:

${ }^{20}$ Ibn Qutaybah, Ta'wil Mukhtalif al-Hadis., 
1. Identifikasi hadis

Sebelum melakukan takwil terhadap hadis mukbtalif, Ibn Qutaybah melakukan identifikasi hadis-hadis tersebut. Identifikasi ini bisa berupa status hadis. Meskipun diakui identifikasi yang dilakukan Ibn Qutaibah tidak detail. Tidak menggunakan takbrij hadis. Ia hanya menggunakan status hadis semisal sahih, hasan atau dhaif. Atau pun menolak karena bukan hadis. Hal ini bisa dilihat ketika ia membahas hadis tentang tasybih bahwa kedua tangan kanan Allah, yang dianggap Mu'tazilah bertentangan dengan logika akal, seandainya yang dimaksud tangan adalah anggota badan. Karena anggota badan sepasang adalah kanan dan kiri. Ia mengatakan bahwa hadis ini adalah sahih dan tidak mustahil bagi akal. Karena yang dimaksud makna kanan disini adalah kemapanan dan kesempurnaan. Karena tangan kiri selalu berarti kurang dari tangan kanan dalam kekuatan, keperkasaan maupun kesempurnaan. Ia berdalih orang-orang Arab sangat menyukai kanan, dan membenci kiri. Karena pada kanan terkandung makna kesempurnaan dan pada kiri kekurangan. Oleh karena itu, mereka berkata keberuntungan (al-yumnu) dan kebuntungan (al-syu'mu). Atau juga bisa dipahami kedua tangan Allah itu kanan bahwa Allah selalu memberi dengan kedua tangannya. Karena tangan pemberi adalah identik dengan tangan kanan. ${ }^{21}$

2. Asbab al-wurud (bila ditemukan)

Melihat asbab al-wurud sebuah hadis amatlah penting dilakukan sebelum memahami pesan-pesannya. Itulah yang dilakukan Ibn Qutaybah ketika membahas hadis tentang larangan Nabi saw. untuk mencela al-dabr (waktu), karena Allah Swt. adalah al-dahr. Hadis ini seakan mendukung pengikut alDahriyah. ${ }^{22}$ Ibn Qutaybah menjelaskan dalam hal ini bahwa

${ }^{21}$ Ibn Qutaybah, Ta'wil Mukhtalif al-Hadits., hlm. 193-194

22 Al-Dahriyah adalah kelompok filsafat yang mengatakan bahwa segala sesuatu yang terjadi di dunia ini secara kebetulan, tidak ada Tuhan yang 
hadis Nabi ini muncul karena kebanyakan orang-orang Arab Jahiliyyah adalah al-Dahriyyah, meyakini waktu adalah segalanya. Hidup ini adalah bentangan waktu, hidup dan mati karena waktu.

3. Melakukan takwil terhadap salah satu hadis yang bertentangan

Hadis tentang doa Nabi agar dihidupkan miskin, dimatikan miskin dan dibangkitkan bersama orang-orang miskin. Hadis ini bertentangan dengan doa Nabi berlindung dari kefakiran. ${ }^{23}$ Menurut Ibn Qutaybah berkata bahwa kata miskin tidak selalu bermakna kefakiran harta, namun juga bermakna ke-tawadbu'-an (kerendahan hati). Sering orang Arab menggunakan kata miskin dengan maksud ini. Maka kata miskin dalam hadis pertama adalah ke-tawadhu'-an, sehingga tidak bertentangan dengan hadis kedua. Oleh karena itulah, Nabi tidak mengatakan dalam do'anya: "Allabumma abyini faqiran..."

4. Melakukan takwil terhadap dua hadis yang bertentangan

Untuk mendapatkan pemahaman yang tepat terhadap dua hadis yang bertentangan, Ibn Qutaybah melakukan takwil terhadap keduanya. Sebagai contah, hadis tentang al-'Adwa' wa al-Thirah yaitu sabda Rasulullah, 'Tidak ada 'adwa' dan tidak ada thirah." '24 'Adwa adalah penularan penyakit, sedangkan thirah adalah keyakinan orang Arab Jahiliyyah tentang prediksi nasib baik dan buruk dengan melihat aktifitas burung. Bila seorang hendak keluar rumah kemudian melihat burung terbang ke sebelah kanan, berarti akan bernasib baik. Tapi, sebaliknya bila burung terbang ke arah kiri maka akan bernasib buruk. Hadis ini bertentangan dengan hadis larangan Nabi kepada pengembala unta untuk tidak mencampur unta yang sehat

mengaturnya. Mereka tidak mengakui adanya hari pembalasan, hari kebangkitan dan lain sebagainya terkait akhirat. Lihat Ibnu Hazm, al-Fasl fi al-Milal wa alAbwa wa an-Nihal, (Kairo: Maktabah al-Khanji, tt.), Juz ke-1, hlm. 155.

${ }^{23}$ Ibn Qutaybah, Ta'wil Mukhtalif al-Hadits., hlm. 154.

${ }^{24}$ Ibn Qutaybah, Ta'wil Mukhtalif al-Hadits., hlm. 96. 
dengan unta yang sakit kulit. Begitu juga hadis tentang perintah Nabi agar menjauh dari penderita kusta seperti berlari dari Harimau. Ibn Qutaybah mengatakan bahwa masing-masing hadis punya makna sendiri pada waktu dan kondisinya masingmasing. Bila ditempatkan pada waktu dan kondisi yang tepat tidak akan ada pertentangan. Hadis pertama diperuntukkan bagi keyakinan Arab Jahiliyyah bahwa penyakit ada dengan sendirinya dan menular dengan sendirinya. Sebagai bukti Nabi mengutarakan pertanyaan: "Siapa yang menularkan penyakit pada yang pertama?" Dan keyakinan mereka bahwa nasib baik-buruk dapat diprediksi melalui burung yang terbang ke kiri atau ke kanan. Sedangkan hadis larangan mencampur unta sehat dengan unta sakit, agar menghilangkan rasa bersalah andai kata terjadi penularan. Dan hadis menjauhi penderita kusta dimaksudkan agar orang-orang sehat tidak terganggu dengan bau yang menyengat dari penderita. Bila interaksi yang begitu lama bisa jadi mereka akan jatuh sakit karena aroma dan iklim yang tidak kondusif untuk kesehatan.

5. Memperkuat takwilnya dengan teks-teks lain

a. Dengan ayat al-Qur'an

Untuk memperkuat pemahaman hadis mukbtalif dengan takwilnya, Ibnu Qutaibah menggunakan ayat alQur'an sebagai penguat. Sebagai contoh dalam hadis yang dipertentangkan oleh Mu'tazilah bahwa apakah Nabi sebelum diutus beragama seperti kaumnya atau tidak. ${ }^{25}$ Ada dua riwayat yang bertentangan. Pertama, riwayat yang menegaskan bahwa tidak ada Nabi pun yang kufur kepada Allah. Kedua, riwayat yang menjelaskan bahwa Nabi Muhammad selama 40 tahun beragama seperti agama kaumnya, dan menikahkan kedua putrinya dengan dua orang kafir. Menurut Ibn Qutaybah semua orang Arab kecuali Yaman adalah keturunan Nabi Ismail bin Ibrahim a.s.

${ }^{25}$ Ibn Qutaybah, Ta'wil Mukbtalif al-Hadits., hlm. 104. 
Sebelum diutus Nabi Muhamad mereka masih berpegang dengan sebagian ajaran Nabi Ibrahim. Seperti berhaji, khitan, nikah, talak, diyat (tebusan) nyawa, mandi junub, percaya dengan hari akhir.

Maka maksud riwayat bahwa Nabi atas agama kaumnya adalah dalam keimanan dan menjalankan syariat Nabi Ibrahim. Namun dapat dipastikan Nabi tidak pernah menyentuh berhala. Dengan bukti riwayat: "Aku diberikan rasa benci terhadap berhala." Walaupun begitu Nabi tidak mengetahui rincian detail fardhu-fardhu Allah sampai beliau diberi wahyu.

b. Dengan hadis lain

Hadis tentang Nabi melihat Allah dalam peristiwa Isra' Mi'raj. ${ }^{26}$ Hadis ini bertentangan dengan ayat al-Qur'an (QS. Al-An'am [6]: 103) bahwa Allah tak dapat dilihat oleh mata manusia. Ibn Qutaybah mencoba menjawab bahwa ayat alQur'an itu berbicara penglihatan dengan mata telanjang tubuh manusia di dunia. Sedangkan Nabi melihat Allah merupakan dengan mata ruhnya. Di sini, tampak Ibn Qutaybah, mengikuti kaum Mu'tazilah bahwa Nabi melakukan Isra' Mi'raj dengan ruh tanpa jasad. Hal ini, menurut Ibn Qutaibah dikuatkan dengan riwayat istri-istri Nabi yang mengatakan tidak kehilangan fisik Nabi pada malam Isra' dan Mi'raj.

c. Dengan bait syair

Dalam menguatkan takwilnya terhadap matan-matan hadis mukhtalif, Ibn Qutaybah tidak jarang menggunakan bait-bait sya'ir. Sebagai contoh ketika menakwilkan hadis silaturrahim dapat menambah umur. Riwayat ini menurut Mu'tazilah bertentangan dengan firman Allah Surat al-Naml ayat 61 yang menegaskan bahwa ajal tidak dapat dipercepat

${ }^{26}$ Ibn Qutaybah, Ta'wil Mukhtalif al-Hadits., hlm. 198.

154 | TAJDID vol. 19, No. 2, Juli - Desember 2020 
atau diperlambat, karena sudah ditetapkan oleh Allah. ${ }^{27}$ Menurut Ibn Qutaybah maksud menambah umur ini, ada makna. Pertama, keluasan dan bertambah rezeki, kesehatan badan. Karena kesempitan rezeki atau kefakiran sering disebut sebagai kematian yang paling besar. Sebagaimana dijelaskan dalam bait syair:

"Bukannya orang yang mati dapat beristirahat dengan kematiannya. Sesunggubnya orang mati seperti itu adalah orang-orang mati yang bidup."

Maksud orang-orang mati yang hidup disini adalah orang yang hidup dengan penuh kefakiran. Kalau boleh mengatakan kefakiran sebagai kematian, dan sebagai kekurangan hidup maka boleh mengatakan kekayaan sebagai kehidupan dan menambah umur.

d. Dengan logika

Hadis tentang Nabi Musa a.s. mencolok mata malaikat maut saat hendak menjemputnya. ${ }^{28}$ Hadis ini bertentangan dengan logika akal manusia, bagaimana mungkin manusia dapat melukai malaikat, yang Allah muliakan. Ibn Qutaybah mengatakan, malaikat adalah makhluk ruhani yang Allah berikan kemampuan berubah wujud. Seperti yang dijelaskan dalam riwayat-riwayat lain bahwa Nabi pernah bertemu dengan malaikat Jibril dalam bentuk seorang manusia. Maka hadis tadi berkaitan dengan penampakan malaikat dalam wujud manusia, sehingga berlaku hukum tubuh manusia, seperti dipukul, dicolok dan sebagainya. Artinya, Nabi Musa a.s. mencolok mata malaikat maut ketika menjelma manusia yang memiliki tubuh.

${ }^{27}$ Ibn Qutaybah, Ta'wil Mukhtalif al-Hadits., hlm. 187.

${ }^{28}$ Ibn Qutaybah, Ta'wil Mukbtalif al-Hadits., hlm. 252. 
e. Dengan fakta sejarah

Dalam pembahasan Hadis yang mengungkapkan bahwa Nabi disihir oleh seorang dukun Yahudi Madinah, melalui media benda yang diikat dalam sumur $\mathrm{Zi}$ Arwan. Menurut Mu'tazilah bagaimana mungkin Nabi terkena sihir yang merupakan perbuatan syaithan. Sedangkan beliau selalu dijaga oleh Allah dan selalu diturunkan wahyu. ${ }^{29}$ Ibn Qutaybah menjelaskan, menolak adanya sihir adalah menolak fakta sejarah yang sudah ada di kalangan muslimin, Yahudi maupun Nasrani ataupun semua ahli Kitab. Bahkan sihir sudah dikenal oleh seluruh umat di dunia sejak dulu, seperti Bangsa India, Romawi, Arab Jahiliyyah dan seterusnya. Belum lagi al-Qur'an menguatkan fakta ini seperti terangkum dalam Surat al-Falaq. Apa yang terjadi pada Nabi dari upaya pembunuhan yang dilakukan seorang Yahudi melalui sihir, bukanlah hal yang mustahil. Kaum Yahudi sebelumnya pernah membunuh nabi-nabi mereka, seperti Nabi Zakaria bin Azan dan Nabi Yahya a.s. Di samping itu, tipu daya syaithan terhadap para Nabi pun bukan suatu kemustahilan. Dalam fakta al-Qur'an, diceritakan Nabi Ayub a.s. mengeluhkan penderitaannya berupa penyakit akibat ulah syaithan, seperti terekam dalam Surat Shaad ayat 41.

f. Dengan ilmu pengetahuan

Selain menggunakan fakta sejarah dalam menakwilkan hadis musykil, Ibn Qutaybah pun mencoba mengidentifikasi kebenaran matan hadis dengan ilmu pengetahuan yang sesuai.

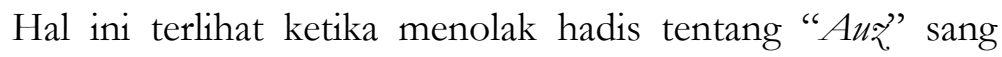
monster pada zaman nabi Musa selain dengan alasan ilmu periwayatan, juga ditinjau dari aspek ilmu fosil. Menurutnya, hadis-hadis tentang mitologi manusia raksasa perlu diwaspadai sebagai hadis maudhu'. Hadis-hadis sejenis banyak

${ }^{29}$ Ibn Qutaybah, Ta'wil Mukhtalif al-Hadits., hlm. 164-172.

156 | TAJDID vol. 19, No. 2, Juli - Desember 2020 
didapat dalam literatur hadis. Sebagai contoh lain, hadis tentang besar tubuh Nabi Adam a.s. yang digambarkan bila berdiri kepalanya menyentuh awan sehingga bergesekan dan menyebabkan kepalanya gundul. Ketika ia diturunkan dari syurga dan menangis sehingga air matanya menjadi lautan yang dapat menghanyutkan perahu. Hadis lain, tentang Nabi Daud a.s. yang bersujud selama 40 malam dengan menangis sehingga air matanya menumbuhkn rumput. Kemudian ia menarik nafas panjang sehingga pohon-pohon di sekitarnya bergoyang. Hadis lain tentang tongkat nabi Musa a.s. yang digambarkan batangnya seperti batang pohon korma yang tinggi, matanya seperti kilatan petir menyambar. Hal-hal yang digambarkan dalam riwayat-riwayat mitos itu terlalu berlebihan, tidak seperti yang digambarkan Allah dalam alQur'an. Kita tahu bahwa mereka seperti Nabi Adam, Musa, Daud, fisik mereka lebih besar dari fisik kita sekarang, lebih kuat dari kita, tapi ukuran fisik antara kita dengan mereka sesuai dengan umur yang Allah berikan kepada kita dan mereka. Sebagai contoh, nabi Adam a.s. diberikan umur seribu tahun, seperti yang dikisahkan dalam riwayat-riwayat dan kitab Taurat. Nabi Nuh a.s. menetap di kalangan kaumnya selama 950 tahun. Kemudian umur manusia terus berkurang setelah nabi Nuh a.s., kecuali riwayat yang menjelaskan umur Lukman al-Hakim yang diberi umur 2.450 tahun lebih. Ini cerita umat terdahulu, yang tidak ada beritanya dalam al-Qur'an dan hadis, namun Allah Swt. telah memberikan kita ukuran mereka dengan melihat bukti-bukti yang telah mereka tinggalkan di bumi. Seperti bangunan, benteng yang telah mereka bangun yang di buat di gunung bebatuan. Dari sini tampak bahwa tidak ada perbedaan fisik yang begitu jauh antara kita dengan mereka kecuali dalam umur. Ibn Qutaybah melansir riwayat tentang fosil yang ditemukan dari riwayat Riyasi yang menceritakan pada zaman Khalid bin Abdullah Hafr al-Mubarak. Ketika itu para 
pekerja menemukan fosil gigi geraham yang beratnya sembilan pond, kita tidak tahu apakah itu gigi manusia atau gigi unta?! kemudian juga ditemukan fosil tulang dagu manusia raksasa, ini pun bisa jadi tulang dagu seekor unta yang banyak ditemukan di Arab, yang dikira sebagai tulang dagu manusia. Karena tulang dagu manusia memiliki bentuk khusus, ada sambungan ke tulang kepala. ${ }^{30}$

Di sini Ibn Qutaybah menggunakan dasar-dasar ilmu arkeologi meskipun dalam bentuk yang sederhana dalam mengukur kebenaran hadis-hadis mitos. Suatu hal yang agak unik bagi seorang mubaddis mengungkapkan suatu fakta riwayat dengan meninjau ilmu arkeologi.

6. Bila tidak mungkin menakwilkan maka dilakukan nasikhmansukh atau melakukan tariih

a. Memberlakukan nasikh-mansukh

Seperti yang dilakukan pada bahasan hadis tentang pernikahan seorang laki-laki yang memadu istrinya dengan bibinya. $^{31}$ Terdapat dua riwayat yang menjelaskan tentang pelarangan pernikahan campur antara wanita dengan bibinya. Riwayat pertama, Nabi melarang seseorang memadu istrinya dengan bibinya dari pihak ayah atau ibu. Riwayat kedua, Nabi melarang pernikahan terhadap saudara se-susuan seperti saudara kandung. Menurut Mu'tazilah riwayat-riwayat ini bertentangan dengan ayat-ayat al-Qur'an, ayat 33 Surat alNisa' yang hanya mengharamkan pernikahan dengan Ibu dan saudara perempuan. Di sini tidak disebutkan pelarangan nikah campur antara wanita dengan bibinya. Ataupun ayat hanya melarang pernikahan dengan ibu susuan dan saudara perempuan se-susuan bukan dengan yang lainnya (bibi). Hal ini dikuatkan dengan ayat lanjutan al-Nisa' ayat 25, yang

\footnotetext{
${ }^{30}$ Ibn Qutaybah, Ta'wil Mukhtalif al-Hadits., hlm. 256-258.

${ }^{31}$ Ibn Qutaybah, Ta'wil Mukbtalif al-Hadits., hlm. 179-180.
} 
menghalalkan selain itu, maka termasuk menikahi seorang wanita atas bibinya baik dari pihak ayah maupun ibu.

b. Melakukan tarjih

Sebagai contoh ketika membahas hadis tentang seorang Badui buang air kecil di Masjid, di sini terdapat dua riwayat. Pertama, riwayat Abu Hurairah yang menjelaskan bahwa Nabi memerintahkan sahabat yang hadir untuk menuangkan satu ember air di atas tanah yang terkena air seninya. Kedua, riwayat Jarir bin Hazim dari Abdul Malik bin Umair dari Abdullah bin Ma'qal bin Muqarrin yang menjelaskan bahwa Nabi memerintahkan sahabat yang hadir untuk membuang tanah yang terkena air seni itu, kemudian menyiram bekasnya dengan air. Ibnu Qutaybah menjawab, pertentangan dalam dua riwayat ini bersumber dari para perawinya. Hadis riwayat Abu Hurairah lebih sahih ketimbang kedua riwayat Jarir bin Hazim. Alasan Ibn Qutaybah bahwa Abdullah bin Muqarin bukan sahabat, tidak pernah bertemu Nabi, maka riwayatnya tidak dapat disejajarkan dengan riwayat sahabat yang hadir dan menyaksikan peristiwa itu. Memang ayahnya, Ma'qal bin Muqarrin Abu Amrah al-Muzni, meriwayatkan dari Nabi sedangkan anaknya, Abdulah, tidak diketahui periwayatannya dari Nabi. Pendapatnya dikuatkan oleh pernyataan Abu Daud bahwa Abdullah bin Ma'qal bukan sahabat, riwayatnya adalah mursal. Di sini Ibn Qutaybah melakukan tarjih terhadap riwayat Abu Hurairah atas riwayat Abdullah bin Ma'qal bin Muqarrin.

Perlu diberikan catatan bahwa ketika ada hadis yang memang sudah tidak bisa di-ta'wil maka beliau mengembalikan kepada Allah tentang pengetahuannya dan dan berdoa agar diberikan petunjuk dari Allah Swt. agar terlindung dari segala perbuatan atau penakwilan yang salah. 
Dalam analisa penulis, hal yang menjadi sebuah keunggulan dari kitab ini adalah Ibn Qutaybah menyusun kitab ini sedemikian baik dengan mengambil makna yang dilihat dari berbagai kacamata bidang keilmuan yang mana mendapat pujian dari Ibn Shaba. Kemudian menjawab tantangan pada saat itu yakni terjadi pergolakan agar kitab ini menjadi penenang bagi masalah yang terjadi. Dan yang menjadi kekurangan adalah pada saat beliau melihat suatu hadis, cara melihatnya tidak secara menyeluruh, melainkan hanya sebatas sahih, dhaif, hasan dan sebagainya, yang mana hal ini menjadi sebuah kelemahan dari kitab ini.

Seorang ulama yakni Ibn Shalah pernah mengomentari kitab Ta'wil Mukbtalif al-Hadits ini. Dalam kitab Muqaddimah-nya, beliau berkata:

"Kitab ini begitu istimewa karena muncul di era ketika para penggiat ilmu hadis belum memiliki kemampuan paripurna dalam melindungi hadis dan mengkritisi argumen para penentang hadis secara ilmiah dan metodologis, bahkean kitab ini tampil dengan metode ilmiah pada saat perangkat ilmu badis belum terbentuk secara sistematis." 32

\section{Kategorisasi Kitab Ta'wil Mukhtalif al-Hadits sebagai Kitab Hermeneutika Hadis Klasik}

Singgungan kitab Ta'wil Mukhtalif al-Hadits ini sehingga dikategorikan sebagai sebuah kitab yang berbasis hermeneutika adalah seperti yang dijelaskan di atas bahwa hermeneutika mempunyai tiga makna, yaitu mengatakan (to say); menjelaskan (to explain); dan menerjemahkan (to translate). Yang dalam bahasa Inggris diekspresikan dalam kata "to interpret". Yakni sebuah interpretasi yang menunjukkan pada tiga hal pokok, pengucapan lisan, penjelasan yang masuk akal, dan terjemahan dari bahasa lain. ${ }^{33}$ Ketiga hal tersebut secara nyata dilakukan oleh Ibn Qutaybah dalam kitabnya tersebut, untuk mendapatkan makna

32 Ibnu Shalah, Muqaddimah Ibn al-Shalah, (Kairo: Dar al-Anshar, 1400 H), hlm. 143.

${ }^{33}$ Nasaruddin Umar, Deradikalisasi Pemahaman al-Qur'an dan Hadis, hlm. 66. 
yang sebenarnya lewat hadis yang disampaikan oleh Nabi Muhammad saw.

Ketiga makna hermeneutika yang dilakukan oleh Ibn Qutaybah tersebut, bukan tanpa mendasar, namun semuanya terlihat ketika beliau melihat sebuah hadis, yang secara leterlek dapat dilihat bertentangan, namun setelah dikaji ulang dengan melihat apa yang dikatakan oleh Nabi, bagaimana Nabi menjelaskan, kemudian Ibn Qutaybah mencoba menerjemahkannya dengan berbagai metode yang dipakai oleh beliau dalam mendapatkan makna yang sebenarnya dari sebuah hadis Nabi saw.

Dalam penjelasan lain tentang klasifikasi kitab ini sebagai kitab hermeneutika hadis adalah dari segi metode yang dipakai Ibn Qutaybah itu sendiri. Ilmu hermeneutika hadis memang baru ada pada masa setelah kitab tersebut muncul, namun kitab Ta'wil Mukhtalif al-Hadits, tergolong sebagai sebuah kitab hermeneutika hadis dikarenakan karena, dari segi metode dalam menjelaskan hadis diiringi dengan berbagai ilmu pengetahuan lain, maka kitab tersebut dapat termasuk dalam golongan kitab hermeneutika hadis yang klasik, walaupun Ibn Qutaybah sendiri tidak mengklasifikasi kitab tersebut sebagai sebuah kitab hermeneutika.

\section{Penutup}

Penyusunan kitab Ta'wil Mukbtalif al-Hadits dilatarbelakangi atas respons terhadap pergolakan politik saat Ibn Qutaybah masih hidup, dengan menepis anggapan sebagian golongan yang menuduh ulama hadis telah melakukan kecerobohan, dengan meriwayatkan hadis yang dianggap saling berlawanan maupun tidak sejalan dengan al-Qur'an dan pemahaman akal, serta mengamalkan hadis-hadis yang bertentangan dengan kemahasucian Allah Swt. Pada langkah penyelesaian sebuah hadis dalam kitab Ta'wil Mukhtalif al-Hadits, Ibn Qutaybah melakukan identifikasi hadis, melihat asbab al-wurud (bila ditemukan), melakukan takwil terhadap salah satu hadis yang bertentangan, melakukan takwil terhadap dua 
hadis yang bertentangan, memperkuat takwilnya dengan teks-teks lain (al-Qur'an, hadis, bait syair, bahkan dengan logika), kemudian bila tidak mungkin menakwilkan maka dilakukan nasikh-mansukh atau melakukan tariih.

Klasifikasi kitab ini sehingga menjadi kitab hermeneutika hadis adalah dilihat dari segi metode yang dipakai Ibn Qutaybah itu sendiri. Ilmu hermeneutika hadis memang baru ada pada masa setelah kitab tersebut muncul, namun kitab Ta'wil Mukbtalif alHadits, tergolong sebagai sebuah kitab hermeneutika hadis dikarenakan, dari segi metode dalam menjelaskan hadis diiringi dengan berbagai ilmu pengetahuan lain, maka kitab tersebut dapat termasuk dalam golongan kitab hermeneutika hadis yang klasik, walaupun Ibn Qutaybah sendiri tidak mengklasifikasi kitab tersebut sebagai sebuah kitab hermeneutika.

\section{Daftar Pustaka}

Abu Zahw, Muhammad, al-Hadits wa al-Mubadditsun, Riyadh: alMaktabah al- 'Arabiyyah al-Su'udiyyah, 1984.

Al-Khatib, Muhammad 'Ajjaj, Ushul al-Hadits 'Ulumubu wa Musthalahubu, Beirut: Dar al-Fikr, 2009.

Azra, Azyumardi, dkk, Ensiklopedi Islam, vol III, Jakarta: Ikhtiar Baru van Hoeve, 2005.

Hasan, Ahmad, The Doctrine of Ijma', Islamabad: Islamic Research Institute, 1978.

Hasyim, Ahmad Umar, Qawa'id Ushul al-Hadits, Beirut: Alimul Kutub, 1997.

Hazm, Ibnu, al-Fasl fi al-Milal wa al-Ahwa wa an-Nibal, Kairo: Maktabah al-Khanji, tt.

Ismail, M. Syuhudi, Hadis Nabi Menurut Pembela Pengingkar dan Pemalsunya, Jakarta: Gema Insani Press, 1995.

Kurdi dkk, Hermenentika al-Qur'an dan Hadis, disunting oleh Sahiron Syamsuddin, Yogyakarta: eLSAQ Press, 2010. 
Ma'luf, Louis, al-Munjid fi al-Lughah, Beirut Darul-Masyriq, 2002, Cet. Ke-39.

Manzhur, Ibnu, Lisanul Arab, Beirut Darul Fikr, 1990.

Qutaybah, Abu Muhammad 'Abdullah bin Muslim, Ta'wil Mukbtalif al-Hadits, Beirut: al-Maktab al-Islami, 1999.

Shalah, Ibnu, Muqaddimah Ibn al-Shalah, Kairo: Dar al-Anshar, 1400 $\mathrm{H}$.

Umar, Nasaruddin, Deradikalisasi Pemahaman al-Qur'an dan Hadis, Jakarta: PT Elex Media Komputindo, 2014.

Yatim, Badri, Sejarah Peradaban Islam, Jakarta: Raja Grafindo Persada, 1995. 